\title{
FROM LEISURE
}

\author{
Angelo V. Suarez \\ alimango@gmail.com
}

\begin{abstract}
About the Author
Angelo V. Suarez is a poet from Manila. Most of his work is freely downloadable online. His latest, Philippine English: A novel, is forthcoming from GaussPDF. He earns his living in advertising.
\end{abstract}

\section{About the Work}

Leisure is a collage of excerpts from Filipino poets' bios from various published books, in which they disclose what jobs they hold for the accumulation of capital other than the writing of poetry. Considering that the production of books of poetry by Filipinos has not ended, the collage is not expected to be completed, and will keep getting published in its unfinished form. A work about work, Leisure is forever a work in progress. 
He teaches at the Filipino Department of Ateneo de Manila University.

He also fronts the spoken word-jazz-rock band Radioactive Sago Project and currently works as a host and writer for the News and Public Affairs programs of TV5.

She teaches creative writing and literature at the University of the Philippines in Diliman.

He serves as Philippines editor for MANOA: A Pacific Journal of International Writing, published by the University of Hawai'i. He contributes a weekly literature and culture column to a national broadsheet, The Philippine Star, and a monthly column to Illustrado magazine that is published in Dubai. He teaches fiction and poetry at Ateneo de Manila University, where he held the Henry Lee Irwin Professorial Chair.

Kasalukuyan siyang full professor sa Unibersidad ng Pilipinas (Diliman) at editor-in-chief ng Bulawan, pambansang refereed journal sa sining at kultura ng National Commission for Culture and the Arts.

He is a longtime editor and writer.

He is a faculty member of the University of Sto. Tomas Conservatory of Music, where he graduated with Music Literature and Piano Performance degrees. He occasionally writes music reviews for the Philippine Daily Inquirer.

He teaches Literature at Miriam College, Quezon City, Philippines.

He is a literature professor at Miriam College, also in Quezon City.

He is the current Literary Editor of the Philippines Free Press magazine. He teaches literature at Miriam College.

With more than 30 full-length films and a hundred shorts under his belt including Squatterpunk (Rotterdam), The Muzzled Horse of an Engineer in Search of Mechanical Saddles (Berlinale), and Manila in the Fangs of Darkness (Viennale), he has been called the Father of Philippine Filmmaking. He is the festival director of .MOV International Film, Music, \& Literature Festival. He is also an award-winning pianist, songwriter, and composer. 
Siya ay naging instruktor sa panitikan, kritisismo at malikhaing pagsulat sa UP Los Baños.

He works as a Regional Trial Court judge in Cebu City.

He works in the Correspondence Office of the Office of President Benigno Aquino III.

As critic, she is one of the founding members of the Manila Critics Circle which gives out the National Book Awards annually. As academician, she was Dean of the Faculty of Arts and Letters, University of Santo Tomas for nine years. She is now handling subjects in the Graduate School as Full Professor, concurrently holding the position of Director of the UST Center for Creative Writing and Studies.

He is the Chancellor at the University of the Philippines in Mindanao.

Siya ay guro ng Wika, Panitikan at Malikhaing Pagsulat.

Nagsimula siyang magturo sa Ateneo de Manila University noong 1961 at doon ay nagging tagapangulo ng Department of Philippine Studies. Naging bahagi ng kaguruan ng Kagawaran ng Filipino at Panitikan ng Pilipinas ng College of Arts and Letters, University of the Philippines noon 1976. Bagaman nagretiro na siya noong 1997, patuloy siyang naglilingkod bilang Professor Emeritus ng nasabing institusyon. Mula noong 1998, Visiting Professor at naglilingkod din siya bilang coordinator ng Philippine Studies Program ng Department of Literature and Philippine Languages ng College of Liberal Arts ng De La Salle University.

He is co-author of the recently released APA Insight Guide to the Philippines and is currently Publications Editor of the University of the Philippines President's Council on the Arts.

She holds the honor of being the first Elisabeth Luce Moore Distinguished Asian Professor. For over thirty years she has co-directed the Creative Writing Program at Silliman University with her husband.

He has also been a documentary filmmaker and scriptwriter-for which he has won a FAMAS and Catholic Mass Media Award for feature film screenplay-as well as a book, magazine and newspaper editor and designer. He serves as Philippines Editor for MANOA: A Pacific Journal of International Writing, published by the University of Hawai'i. He contributes a weekly literature and culture column to 
The Philippine Star and teaches fiction and poetry at Ateneo de Manila University, where he held the Irwin Lee Professorial Chair in 1999.

Kasapi siya ng Kabulig-Bikol at kolumnista sa Bicol Mail.

He has been the recipient of various writing or research grants/fellowships from the Cultural Center of the Philippines, University of the Philippines Creative Writing Center, the UP Center for Integrative and Development Studies, and the International House of Japan. He wrote the full text of Asean Sculptures published by the Association of Southeast Asian Nations. He has edited some literary and cultural journals. As a social anthropologist, he has mounted two museological exhibits at CCP and Nayong Pilipino. His books on Philippine political and ethnic culture include Just Vexations, Beddeng, Reinventing the Filipino Sense of Being and Becoming, and Beyond the Cult of Dissidence in the Southern Philippines. He is a research fellow at the UP Center for Integrative and Development Studies, and a lifetime member of the Philippine Anthropological Society, and of the International House of Japan, a cultural exchange center based in Tokyo.

He has taught at the University of the Philippines (Diliman, Manila, and Los Baños) and at De La Salle University where he also worked for three years in the university press. After writing for Jingle, National Midweek, Business World, Evening Paper, Agencia EFE and Graphic, he is now deskman at the Philippine Star.

Higit sa pagsusulat, pagtuturo at pag-eehersisyo, iniuukol niya ang panahon sa development work. Ngayo'y lublob siya sa larangan ng humanitarian assistance, climate change at disaster risk reduction.

He works in government.

Before this, he was teaching in the Department of English at the Ateneo de Manila University, where he was coordinator for undergraduate studies in literature.

He is a writer, cultural worker, teacher of writing and former professor of literature. He has taught at Silliman, at Mindanao State University, at Baguio Colleges Foundation and at the University of the Philippines Baguio. He has been panelist at the Silliman (later Dumaguete Writers') Workshop, at the UP Writers' Workshop, the Western Mindanao Writers' Workshop in Zamboanga City and the Cordillera Writers' Workshop in UP Baguio. He was a member in 2004 to 2007 of the Executive Committee for Literary Arts of the National Commission for Culture and the Arts.

He is a bookmaker by trade. 
She is committed as a midwife.

He is a faculty member of the English Department at the Ateneo de Manila University. He is the Associate Editor for the literary section of Kritika Kultura, as well as one of the editors of the Kritika Kultura Anthology of New Philippine Writing in English (2011).

He teaches writing and literature at the Ateneo de Manila University, where he edits the literary section of the academic journal Kritika Kultura.

He is also an educator and cultural entrepreneur.

She holds the honor of being the first Elisabeth Luce Moore Distinguished Asian Professor. For over thirty years she has co-directed the National Writers Workshop, and the Creative Writing Program at Silliman University with her husband, Edilberto. She has also published textbooks, some of them in collaboration with her late husband.

He has been a zinester and a bookmaker by trade since 1999.

He was recently retired as a university professor at the University of the Philippines in Diliman.

He works for the British Council. He edits EuroFilipino Journal, a literarycultural magazine based in Middlesex, UK.

She is a poet and journalist. She writes feature stories for Starweek Magazine and edits news reports for The Philippine Star.

He is a desk editor at The Philippine Star, a national daily.

She sings and plays guitar for the Los Angeles-based band The Velvet Ash.

He teaches literature at Silliman University.

As a program coordinator and creative writing teacher for Young Chicago Authors, he has worked with teens in the Chicago Public Schools, the Alternative High Schools, Cook Country Juvenile Detention Center, and Gallery 37 for over six years. 
She heads the Bienvenido N. Santos Creative Writing Center of De La Salle University in Manila, where she teaches with the Literature Department. She is a University fellow and a Metrobank Outstanding Teacher Awardee.

She has been active in social justice work with youth and communities of color in the US for the past 11 years.

He has been reincarnated as a roving security officer in Los Angeles, California.

He teaches literature and creative writing in University of the Philippines Diliman.

He serves as Editor at the North American Review, the oldest US literary magazine, established 1815 .

He is an English professor at the University of Northern Iowa, where he teaches creative writing and multicultural literature.

He is an architect and visual artist, and works as Manager of the Cultural Center of the Philippines' Visual, Literary and Media Art Department.

He teaches part-time at the DLSU College of Saint Benilde and the University of the Philippines Manila.

She has taught at University of the Philippines Baguio, De La Salle University in Manila, and University of Illinois in Chicago. An associate professor on the faculty of the Creative Writing Program and the English Department at Old Dominion University in Norfolk, Virginia, she will be directing the 27th ODU Literary Festival in October 2004.

He is an assistant professor of English at Prairie View A\&M University.

He makes a living as a journalist, screenwriter, book editor, and university lecturer. He's currently Executive Editor of YES Magazine, an entertainment monthly.

He is a poet, translator, journalist, and mountaineer. 